\title{
DIOSCORIDES ON PHARMACY AND MEDICINE
}

History of Science Series, No. 3 


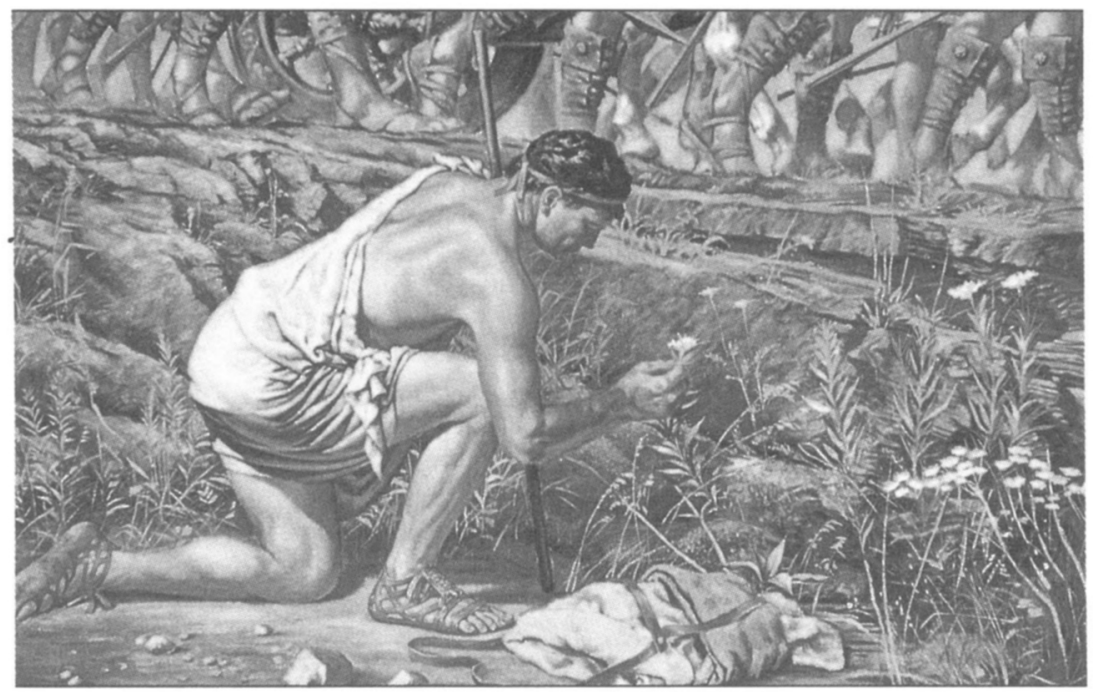

Pedanios Dioscorides, Dioscorides and the Roman legions

(Parke-Davis Great Moments in Pharmacy art series; courtesy Parke-Davis Division of Warner-Lambert Company). 

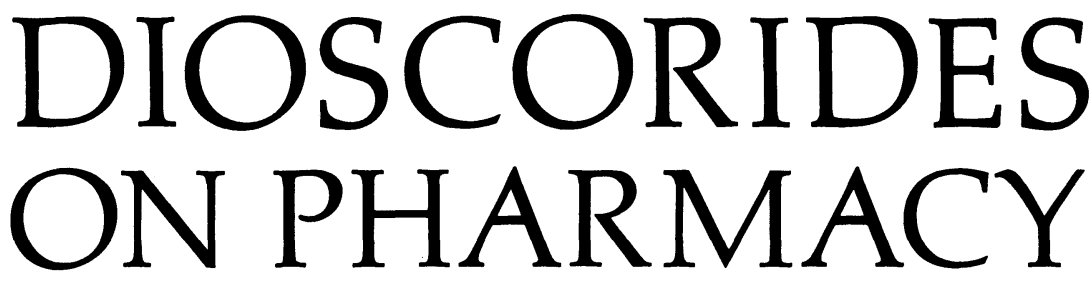

AND MEDICINE

John M. Riddle

FOREWORD BY JOHN SCARBOROUGH

University of Texas Press, Austin $\rightarrow \rightarrow$ 
Copyright (C) 1985 by the University of Texas Press

All rights reserved

Printed in the United States of America

First Edition, 1985

Requests for permission to reproduce material from this work should be sent to Permissions, University of Texas Press, Box 7819, Austin, Texas 78713 .

\section{LIBRARY OF CONGRESS CATALOGING IN PUBLICATION DATA}

Riddle, John M.

Dioscorides on pharmacy and medicine.

(History of science series ; no. 3)

Bibliography: $p$.

Includes index.

1. Dioscorides Pedanius, of Anazarbos. De materia medica. 2. Materia medica-Early works to 1800 .

3. Medicine, Greek and Roman-Early works to 1800 .

4. Medicinal plants-Early works to 1800 . I. Title.

II. Series: History of science series (Austin, Tex.) ; no. 3. [DNLM: 1. Dioscorides Pedanius, of Anazarbos. 2. History of Medicine, Ancient. 3. Pharmacognosyhistory. 4. Pharmacology-history. WZ 100 D594R]

RS79.D563R53 $1985 \quad 615^{\prime} \cdot 321 \quad 85-6220$

ISBN 0-292-71544-7

ISBN 978-0-292-75646-5 (e-book)

ISBN 978-0-292-75647-2 (individual e-book) 
To Margie and Erika 
THIS PAGE INTENTIONALLY LEFT BLANK 